\title{
Front Matter: Volume 6959
}

, "Front Matter: Volume 6959," Proc. SPIE 6959, Micro (MEMS) and Nanotechnologies for Space, Defense, and Security II, 695901 (2 May 2008); doi: $10.1117 / 12.798094$

SDIE Event: SPIE Defense and Security Symposium, 2008, Orlando, Florida, United States 


\section{PROCEEDINGS OF SPIE}

\section{Micro (MEMS) and Nanotechnologies for Space, Defense, and Security II}

Thomas George

Zhongyang Cheng

Editors

18-20 March 2008

Orlando, Florida, USA

Sponsored and Published by

SPIE

Volume 6959 
The papers included in this volume were part of the technical conference cited on the cover and title page. Papers were selected and subject to review by the editors and conference program committee. Some conference presentations may not be available for publication. The papers published in these proceedings reflect the work and thoughts of the authors and are published herein as submitted. The publisher is not responsible for the validity of the information or for any outcomes resulting from reliance thereon.

Please use the following format to cite material from this book:

Author(s), "Title of Paper," in Micro (MEMS) and Nanotechnologies for Space, Defense, and Security II, edited by Thomas George, Zhongyang Cheng, Proceedings of SPIE Vol. 6959 (SPIE, Bellingham, WA, 2008) Article CID Number.

ISSN 0277-786X

ISBN 9780819471505

Published by

SPIE

P.O. Box 10, Bellingham, Washington $98227-0010$ USA

Telephone +1 3606763290 (Pacific Time) · Fax +1 3606471445

SPIE.org

Copyright (C) 2008, Society of Photo-Optical Instrumentation Engineers

Copying of material in this book for internal or personal use, or for the internal or personal use of specific clients, beyond the fair use provisions granted by the U.S. Copyright Law is authorized by SPIE subject to payment of copying fees. The Transactional Reporting Service base fee for this volume is $\$ 18.00$ per article (or portion thereof), which should be paid directly to the Copyright Clearance Center (CCC), 222 Rosewood Drive, Danvers, MA 01923. Payment may also be made electronically through CCC Online at copyright.com. Other copying for republication, resale, advertising or promotion, or any form of systematic or multiple reproduction of any material in this book is prohibited except with permission in writing from the publisher. The CCC fee code is 0277-786X/08/\$18.00.

Printed in the United States of America.

Publication of record for individual papers is online in the SPIE Digital Library.

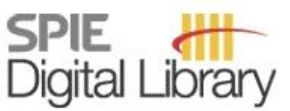

SPIEDigitalLibrary.org

Paper Numbering: Proceedings of SPIE follow an e-First publication model, with papers published first online and then in print and on CD-ROM. Papers are published as they are submitted and meet publication criteria. A unique, consistent, permanent citation identifier (CID) number is assigned to each article at the time of the first publication. Utilization of CIDs allows articles to be fully citable as soon they are published online, and connects the same identifier to all online, print, and electronic versions of the publication. SPIE uses a six-digit CID article numbering system in which:

- The first four digits correspond to the SPIE volume number.

- The last two digits indicate publication order within the volume using a Base 36 numbering system employing both numerals and letters. These two-number sets start with 00, 01, 02, 03, 04, 05, $06,07,08,09,0 \mathrm{~A}, 0 \mathrm{~B} \ldots \mathrm{OZ}$, followed by $10-1 \mathrm{Z}, 20-2 \mathrm{Z}$, etc.

The CID number appears on each page of the manuscript. The complete citation is used on the first page, and an abbreviated version on subsequent pages. Numbers in the index correspond to the last two digits of the six-digit CID number. 


\section{Contents}

vii Conference Committee

ix Introduction

xi Deep space flight of Hayabusa asteroid explorer (Plenary Paper) [6960-100] H. Kuninaka, J. Kawaguchi, Japan Aerospace Exploration Agency (Japan)

xxi Nano-enabled defense opportunities (Keynote Presentation, Abstract Only) [6959-1]

D. L. Polla, Defense Advanced Research Projects Agency (USA)

xxiii Emerging sensors and electron devices for Army applications (Keynote Presentation) [6959-9]

J. Pellegrino, Army Research Lab. (USA)

\section{NANOWIRES AND NANOTUBES}

695903 Wide bandgap nanowire sensors (Invited Paper) [6959-02]

S. J. Pearton, B. S. Kang, B. P. Gila, D. P. Norton, L. C. Tien, H. T. Wang, F. Ren, J. Lin, Univ. of Florida (USA)

695904 Cadmium zinc telluride (CZT) nanowire sensors for detection of low-energy gamma-ray detection [6959-03]

T. Gandhi, K. S. Raja, M. Misra, Univ. of Nevada, Reno (USA)

695905 Controlled growth of ZnO nanorod arrays and their PL properties [6959-04]

M. Wang, Z. Xu, Z. Wang, Y. Xue, J. Zhu, Xi'an Jiaotong Univ. (China)

695906 Application specific electrode-integrated nanotube cathodes (ASINCs) for miniature analytical instruments for space exploration (Invited Paper) [6959-05]

H. M. Manohara, M. J. Bronikowski, R. Toda, E. Urgiles, R. H. Lin, K. Y. Yee, A. B. Kaul, J. Hong, Jet Propulsion Lab. (USA)

695907 Effect of nitrogen gas on the lifetime of carbon nanotube field emitters for electron-impact ionization mass spectrometry [6959-06]

S. A. Getty, R. A. Bis, NASA Goddard Space Flight Ctr. (USA); S. Snyder, Lehigh Univ. (USA);

E. Gehrels, K. Ramirez, T. T. King, P. A. Roman, P. R. Mahaffy, NASA Goddard Space Flight

Ctr. (USA)

695909 Carbon nanotube switches for communication and memory applications [6959-08]

A. B. Kaul, L. Epp, Jet Propulsion Lab. (USA); E. W. Wong, Atomate Corp. (USA);

R. Kowalczyk, Jet Propulsion Lab. (USA) 
6959 OC Development and operation of the microshutter array system (Invited Paper) [6959-10] M. D. Jhabvala, D. Franz, T. King, NASA Goddard Space Flight Ctr. (USA); G. Kletetschka, Catholic Univ. of America (USA); A. S. Kutyrev, Univ. of Maryland, College Park (USA); M. J. Li, S. E. Meyer, S. H. Moseley, S. Schwinger, R. Silverberg, NASA Goddard Space Flight Ctr. (USA)

6959 OD Texas Instruments' DLP products massively paralleled MOEMS arrays for display applications: a distant second to Mother Nature (Invited Paper) [6959-12]

P. I. Oden, Texas Instruments Inc. (USA)

6959 OE Simulation of a miniature, low-power time-of-flight mass spectrometer for in situ analysis of planetary atmospheres (Invited Paper) [6959-13]

T. T. King, S. A. Getty, P. A. Roman, F. A. Herrero, H. H. Jones, D. M. Kahle, B. Lynch,

G. Suárez, W. B. Brinckerhoff, P. R. Mahaffy, NASA Goddard Space Flight Ctr. (USA)

6959 OF Carbon nanotube vacuum gauges utilizing long, dissipative tubes [6959-14]

A. B. Kaul, H. M. Manohara, Jet Propulsion Lab. (USA)

6959 OG A miniature MEMS and NEMS enabled time-of-flight mass spectrometer for investigations in planetary science [6959-15]

P. A. Roman, W. B. Brinckerhoff, S. A. Getty, F. A. Herrero, R. HU, H. H. Jones, D. Kahle,

T. T. King, P. Mahaffy, NASA Goddard Space Flight Ctr. (USA)

\section{DIP PEN NANOLITHOGRAPHY}

6959 Ol Commercially available high-throughput Dip Pen Nanolithography [6959-17]

J. R. Haaheim, E. R. Tevaarwerk, J. Fragala, R. Shile, Nanolnk, Inc. (USA)

6959 0J Application of solid phase direct write (SPDW) via scanning force microscopy for electrical devices and sensors [6959-18]

P. S. Spinney, S. D. Collins, R. L. Smith, Univ. of Maine (USA)

6959 OK Room temperature synthesis of carbon nanotubes using Dip Pen Nanolithography (DPN) [6959-19]

R. V. Gargate, D. Banerjee, Texas A\&M Univ. (USA)

\section{ADVANCED MEMS DEVICES AND FABRICATION}

6959 ON Micromechanical sensors based on conformational change of proteins [6959-22]

X. Yang, K. R. Buchapudi, H. Gao, X. XU, H.-F. Ji, Louisiana Tech Univ. (USA)

6959 OP FPGA platform for MEMS Disc Resonance Gyroscope (DRG) control [6959-24]

D. Keymeulen, C. Peay, D. Foor, Jet Propulsion Lab. (USA); T. Trung, Univ. of California, Berkeley (USA); A. Bakhshi, B\&A Engineering Inc. (USA); P. Withington, K. Yee, R. Terrile, Jet Propulsion Lab. (USA)

$6959 \mathrm{OQ}$ Fabrication and control of an electrostatically levitated rotating gyro [6959-25]

C. D. Ellis, B. M. Wilamowski, Auburn Univ. (USA) 
6959 OS Experimental results of chemical recording using thermally sensitive liposomes [6959-27] M. E. Tanner, Duke Univ. (USA); E. A. Vasievich, Univ. of North Carolina (USA); J. M. Protz, Duke Univ. (USA)

\section{BIOSENSORS}

6959 OW Detection of nucleic acid hybridization via oxide-gated carbon nanotube field-effect transistors (Invited Paper) [6959-31]

K. H. Aschenbach, H. Pandana, J. Lee, Univ. of Maryland, College Park (USA); J. Khan, National Institutes of Health (USA); M. Fuhrer, D. Lenski, R. D. Gomez, Univ. of Maryland, College Park (USA)

6959 0X Photochemical three-dimensional fabrication with nanopore membranes for biological applications [6959-32]

C.-M. Cheng, P. R. LeDuc, Carnegie Mellon Univ. (USA)

6959 OY Development and characterization of a microheater array device for real-time DNA mutation detection [6959-33]

L. Williams, Univ. of Utah (USA); M. Okandan, Sandia National Labs. (USA); A. Chagovetz, S. Blair, Univ. of Utah (USA)

\section{PHOTONIC SENSORS}

695910 Photonic crystals utilized for label-free and amplified fluorescence biodetection (Invited Paper) [6959-35]

B. T. Cunningham, Univ. of Illinois at Urbana-Champaign (USA)

695911 Fine tune localized surface plasmon resonance for chemical and biological sensors [6959-36]

J.-X. Fu, Y.-P. Zhao, Univ. of Georgia (USA)

695912 Passivation of aluminum for micromachining silicon sensors [6959-37]

A. Duan, Vestfold Univ. College (Norway); X. Chen, Vestfold Univ. College (Norway) and Xiamen Univ. (China)

695913 Plasmonic sensors based on nano-holes: technology and integration (Invited Paper) [6959-38]

R. Gordon, D. Sinton, A. G. Brolo, Univ. of Victoria (Canada); K. L. Kavanagh, Simon Fraser Univ. (Canada)

\section{ADAPTIVE OPTICS}

695914 MEMS deformable mirrors for space and defense applications (Invited Paper) [6959-39]

T. G. Bifano, Boston Univ. (USA) and Boston Micromachines Corp. (USA); P. Bierden,

S. A. Cornelissen, Boston Micromachines Corp. (USA) 
695915 Wiregrid micro-polarizers for mid-infrared applications [6959-40]

A. M. Sarangan, A. Mahfoud, Z. WU, Q. Zhan, Univ. of Dayton (USA); D. P. Forrai,

D. W. Endres, J. W. Devitt, L-3 Communications Cincinnati Electronics, Inc. (USA); R. T. Mack, J. S. Harris, Air Force Research Lab. (USA)

\section{POSTER SESSION}

695917 Domain wall resistance in AlFe nanocontact [6959-42]

P. XU, H. San, Xiamen Univ. (China); X. Chen, Xiamen Univ. (China) and Vestfold Univ. College (Norway)

695918 Internationalization of gold and nickel nanowires by living cells [6959-43]

H. YU, Y.-T. Tsai, H. Wang, E. H. Yang, Stevens Institute of Technology (USA)

6959 1A ZnO nanostructures for optoelectronic applications [6959-45]

A. K. Sood, Y. R. Puri, Magnolia Optical Technologies, Inc. (USA); W. Mai, P. Gao, C. Lao, Z. L. Wang, Georgia Institute of Technology (USA); D. L. Polla, DARPA/MTO (USA); M. B. Soprano, DARPA Programs Office, U.S. Army (USA)

6959 1B Modeling nanoscale ink transport in Dip Pen Nanolithography [6959-47]

O. A. Nafday, Nanolnk, Inc. (USA); M. W. Vaughn, Texas Tech Univ. (USA); J. Haaheim, Nanolnk, Inc. (USA); B. L. Weeks, Texas Tech Univ. (USA)

Author Index 


\title{
Conference Committee
}

\author{
Symposium Chair
}

Larry B. Stotts, Defense Advanced Research Projects Agency (USA)

Symposium Cochair

Ray O. Johnson, Lockheed Martin Corporation (USA)

Program Track Chairs

Thomas George, ViaLogy Corporation (USA)

Peter Tchoryk, Jr., Michigan Aerospace Corporation (USA)

Conference Chairs

Thomas George, ViaLogy Corporation (USA)

Zhongyang Cheng, Auburn University (USA)

Program Committee

Debjyoti Banerjee, Texas A\&M University (USA)

Steve Blair, The University of Utah (USA)

Richard W. Cernosek, Sandia National Laboratories (USA)

Xuyuan Chen, Vestfold University College (Norway)

Scott D. Collins, University of Maine (USA)

Xudong Fan, University of Missouri, Columbia (USA)

Ernest J. Garcia, Sandia National Laboratories (USA)

Stephanie A. Getty, NASA Goddard Space Flight Center (USA)

Edward A. Johnson, Ion Optics Inc. (USA)

Mary J. Li, NASA Goddard Space Flight Center (USA)

Cheng Luo, Louisiana Tech University (USA)

Dan Luo, Cornell University (USA)

Harish M. Manohara, Jet Propulsion Laboratory (USA)

Nosang V. Myung, Consultant (USA)

Gregory P. Nordin, Brigham Young University (USA)

Ashok K. Sood, Magnolia Optical Technologies, Inc. (USA)

Kyung-ah Son, Jet Propulsion Laboratory (USA)

Thomas G. Thundat, Oak Ridge National Laboratory (USA)

David V. Wick, Sandia National Laboratories (USA)

Eui-Hyeok Yang, Stevens Institute of Technology (USA) 
Session Chairs

$1 \quad$ Keynote Session I

Ashok K. Sood, Magnolia Optical Technologies, Inc. (USA)

2 Nanowires and Nanotubes

Harish M. Manohara, Jet Propulsion Laboratory (USA)

Stephanie A. Getty, NASA Goddard Space Flight Center (USA)

3 Keynote Session II

Harish M. Manohara, Jet Propulsion Laboratory (USA)

4 Complex MEMS

Todd T. King, NASA Goddard Space Flight Center (USA)

Mary J. Li, NASA Goddard Space Flight Center (USA)

5 Dip Pen Nanolithography

Debjyoti Banerjee, Texas A\&M University (USA)

Gail J. Brown, Air Force Research Laboratory (USA)

6 Advanced MEMS Devices and Fabrication

Orlando Auciello, Argonne National Laboratory (USA)

Scott D. Collins, University of Maine (USA)

$7 \quad$ Nano-bio-info Technologies

Ashok K. Sood, Magnolia Optical Technologies, Inc. (USA)

Xuyuan Chen, Vestfold University College (Norway)

8 Biosensors

Stephanie A. Getty, NASA Goddard Space Flight Center (USA)

Romel D. Gomez, University of Maryland, College Park (USA)

9 Photonic Sensors

Brian T. Cunningham, University of Illinois at Urbana-Champaign (USA)

Reuven Gordon, University of Victoria (Canada)

10 Adaptive Optics

Thomas G. Bifano, Boston University (USA)

Scot S. Olivier, Lawrence Livermore National Laboratory (USA) 


\section{Introduction}

Micro (MEMS) and Nanotechnologies for Space, Defense, and Security is an exciting conference, having successfully completed its third year of operation within the Space Technologies and Operations track at SPIE's Defense and Security Symposium. The combined fields of MEMS and nanotechnologies continue to be a vibrant area of research, as you will see from the papers selected for publication in this volume. The key challenge remains how to effectively transition these new concepts from the laboratory to system-level applications. Invited speakers from Texas Instruments and NASA's Goddard space Flight Center addressed the complex engineering issues involved in converting laboratory-proven concepts into systems that perform reliably in the field. The key insight they provided is that although MEMS and Nanotechnology are the enablers for these next-generation systems, they form only a small portion of the ultimate systems that are fielded. Technology developers need to be made aware of the requirements driven by system-level design for a particular application environment and the intricacies of seamless integration with other sub-components in order to create the final product.

This year, we were also fortunate to have two keynote speakers from DARPA and the Army Research Laboratory, who laid out the roadmaps being pursued by their organizations vis-à-vis MEMS and nanotechnology research and development. In order to achieve the overall goal of successful transition from the laboratory to working product, it is critical that all of the stakeholders, such as the researchers, system developers, and program managers, are fully engaged in the technology transition process.

Among the emerging technologies that we were proud to showcase at this conference were nanowire- and nanotube-based devices, Dip Pen nanolithography, ultra nano crystalline diamond materials, biosensors, plasmonic sensors, and adaptive optics. The novel research presented in these fields is a testament to the diversity of MEMS and nanotechnology and its ability to impact a broad range of applications.

Thomas George Zhongyang Cheng 


\title{
Nano-Enabled Defense Opportunities
}

\author{
D. L. Polla
}

Defense Advanced Research Projects Agency, 3701 North Fairfax Drive, Arlington, VA

MEMS/NEMS have entered a new era characterized by: 1) Insertion of enabling Nanotechnologies, and 2) Heterogeneous integration of multiple technology building blocks. In particular, true systems advantages of MEMS are now being realized - often times through the subtle insertion of nanotechnologies. For instance, ultra miniature chip scale gas analyzers are now being realized through the heterogeneous integration of micro and nano fabricated subcomponents such as chemical pre-concentrators, gas chromatographs, and mass spectrometers. Nanotechnology has enabled all of these key sub-components with advances such as carbon nanotube functionalization of surfaces, nanoelectronic field emitters, and nanodetectors. This talk will focus on several nano-enabled MEMS themes of interest to the Department of Defense and representative of a new direction for MEMS at DARPA. 